\title{
ANALISIS PERILAKU KONSUMEN DALAM BERBELANJA PADA ZAN MART DI KABUPATEN BENGKULU SELATAN
}

\author{
Siti Hanila, Nia Indriasari \\ Program Studi Manajemen Fakultas Ekonomi Universitas Dehasen Bengkulu \\ st.hanila@gmail.com
}

\begin{abstract}
ABSTRAK
Siti Hanila, Nia Indriasari; Tujuan dalam penelitian ini adalah Untuk mengetahui faktor kelengkapan produk dan pelayanan berpengaruh terhadap keputusan membeli dalam berbelanja pada Zan Mart di Kabupaten Bengkulu Selatan. Populasi dalam penelitian ini adalah seluruh konsumen yang kebetulan berkunjung dan membeli di Zan Mart. Pengambilan sampel dengan menggunakan teknik Random sampling yang berjumlah 100 orang.

Dari hasil perhitungan secara simultan diperoleh Fhitung sebesar 48,499 sedangkan Ftabel 3,09 dengan demikian Ho ditolak dan Ha diterima artinya secara simultan kelengkapan produk dan pelayanan berpengaruh signifikan terhadap keputusan membeli pada Zan Mart di Kabupaten Bengkulu Selatan. Secara parsial diperoleh $t_{\text {hitung }} \mathrm{X}_{1}=13,9481$ dan thitung $\mathrm{X}_{2}=7,8455$ dan $\mathrm{t}_{\text {tabel }} 1,98$ artinya Ho ditolak, sehingga secara parsial kelengkapan produk dan pelayanan berpengaruh secara signifikan terhadap keputusan membeli. Kesimpulan dari hasil penelitian yaitu ada pengaruh kelengkapan produk dan pelayanan terhadap keputusan membeli pada Zan Mart di Kabupaten Bengkulu Selatan. Pengaruh secara simultan sebesar $51,2 \%$ dan secara parsial besarnya pengaruh variabel X1=66,5\% dan variabel X2= 38,6\%. Saran yang dapat diberikan adalah pihak Zan Mart hendaknya memperhatikan kelengkapan produk dan yang ditawarkan sehingga konsumen akan merasa puas. Mengenai pelayanan, hendaknya lebih diperhatikan terutama unsur kecepatan, ketepatan, keamanan, keramahan, dan kenyamanan karena variabel pelayanan mempunyai pengaruh cukup besar dalam keputusan membeli pada Zan Mart.
\end{abstract}

\section{ABSTRACT}

Siti Hanila, Nia Indriasari; The purpose of this study is to determine the factors of completeness of products and services have an effect on buying decision in shopping at Zan Mart in South Bengkulu Regency. The population in this study is all consumers who happened to visit and buy in Zan Mart. Sampling using random sampling technique that amounted to 100 people.

From the calculation results simultaneously obtained Fcount of 48.499 while Ftable 3.09 Ho thus rejected and Ha accepted simultaneous means of completeness of products and services have a significant effect on buying decision at Zan Mart in South Bengkulu Regency. Partially obtained by tcount X1 = 13,9481 and tcount $X 2=7,8455$ and table 1,98 means $H o$ is rejected, so partially completeness of product and service have significant effect to buying decision. The conclusion of the research results that there is influence of completeness of products and services to the decision to buy at Zan Mart in South Bengkulu Regency. Effect simultaneously equal to $51,2 \%$ and partially influence of variable $X 1=66,5 \%$ and variable X2 $=38,6 \%$. Suggestions that can be given is the Zan Mart should pay attention to the completeness of the product and offered so that consumers will feel satisfied. Regarding the service, should be more attention especially the element of speed, accuracy, security, friendliness, and comfort because service variables have a big enough influence in the decision to buy on Zan Mart

Key Words: Completeness Of Product, Service And Buying Decision.

\section{LATAR BELAKANG}

Pada masa sekarang ini, pola hidup masyarakat Indonesia semakin maju. Ilmu pengetahuan dan teknologi berkembang begitu pesat seiring dengan perkembangan jaman. Pengaruh perkembangan tersebut sangat nyata, misalnya terciptanya fasilitas-fasilitas yang memudahkan kegiatannya sejalan dengan perkembangan teknologi tersebut. Salah satu dampak dari perkembangan teknologi tersebut adalah semakin banyak berkembang pasar swalayan ataupun minimarket, pusat pembelanjaan yang semakin banyak menawarkan kemudahan, kenyamanan dan keamanan bagi konsumen untuk memenuhi kebutuhan hidupnya secara mudah dan efisien. Dengan banyaknya pusat perbelanjaan yang didirikan maka persaingan antar pusat perbelanjaan semakin tinggi, yang menyebabkan anggota masyarakat atau 
konsumen ingin dilayani lebih baik lagi, sesuai apa yang diinginkan bagi pemenuhan kebutuhan lainnya. Hal ini membuat beban pemasaran semakin berat, karena tugas dari pemasaran merupakan fungsi paling penting dari perusahaan.

Dalam menghadapi persaingan yang semakin ketat, suatu perusahaan perlu memahami perilaku konsumen agar perusahaan mampu bersaing dengan perusahaan sesungguhnya semua kegiatan perusahaan ditujukan untuk memberikan kepuasan kepada konsumen. Perusahaan retail tentunya sadar bahwa dalam era globalisasi pemasaran merupakan kunci dan faktor penting untuk mencapai sukses. Pemasaran memusatkan perhatian pada konsumen karena dengan tercapainya kebutuhan dan kepuasan konsumen akan memberikan keuntungan yang layak dalam jangka panjang. Tujuan kegiatan pemasaran itu sendiri adalah mempengaruhi konsumen untuk membeli barang dan jasa perusahaan pada saat itu yang mereka butuhkan. Menurut William J. Stanton (2003: 5) pemasaran adalah suatu sistem keseluruhan dari kegiatan bisnis yang ditujukan untuk merencanakan menentukan harga, mempromosikan dan mendistribusikan barang dan jasa yang memuaskan kebutuhan baik kepada pembeli yang ada maupunpembelipotensial. Kepuasan adalah tingkat perasaan seseorang setelah membandingkan kinerja yang dirasakan dibandingkan dengan harapannya. Harapan konsumen atau pembeli biasanya dibentuk oleh pengalaman pembelian terdahulu, komentar teman serta janji atau informasi pemasaran dan saingannya. Untuk memenuhi kebutuhan dan memberikan kepuasan tersebut, banyak usaha bisnis kecil-kecilan (usaha pertokoan) berubah menjadi usaha bisnis yang lebih besar (swalayan atau minimarket).Dalam kondisi perekonomian sekarang ini kegiatan pemasaran mempunyai peranan yang sangat sesuai dengan fungsi pemasaran yang merupakan salah satu fungsi pokok yang harus dilakukan oleh perusahaan untuk dapat berkembang dan mendapatkan laba yang maksimal.

\section{LANDASAN TEORI}

\section{Manajemen Pemasaran}

Memilih dan melaksanakan kegiatan pemasaran yang dapat membantu dalam pencapaian tujuan perusahaan serta beradaptasi dengan lingkungan adalah merupakan tujuan seorang manajer pemasaran. Manajemen pemasaran mempunyai proses untuk mempengaruhi tingkat, jangkauan waktu dan komposisi permintaan dengan cara hingga membantu perusahaan mencapai sasarannya. Philip Kotler (2002 : 20) mendefinisikan Manajemen pemasaran adalah analisis, perencanaan, penerapan dan pengawasan terhadap program yang telah dirancang untuk menciptakan, membangun dan mempertahankan pertukaran dan hubungan yang menguntungkan dengan pasar sasaran dengan maksud untuk mencapai tujuan-tujuan organisasi.

Dari definisi tersebut dapat diketahui bahwa fungsi manajemen pemasaran mencakup proses yang melibatkan penganalisaan, perencanaan, pelaksanaan dan pengawasan kegiatan yang dilakukan oleh perusahaan. Kegiatan tersebut bertujuan menimbulkan pertukaran yang diinginkan, baik yang menyangkut kebutuhan psikologi, sosial dan kebudayaan yang dapat disesuaikan dengan sikap dan perilaku konsumen. Bagi perusahaan untuk mendapatkan kelangsungan hidupnya untuk berkembang dan memperoleh keuntungan pemasaran menjadi salah satu kegiatan yang terpenting. Perusahaan yang menitik beratkan usahanya untuk mencapai sukses dalam jangka panjang. Falsafah tersebut disebut konsep pemasaran.

Semua kegiatan perusahaan harus dicurahkan untuk mengetahui apa yang menjadi kegiatan konsumen dan kemudian memuaskan keinginan-keinginan tersebut. Di dalam konsep pemasaran diajarkan bahwa kegiatan pemasaran suatu perusahaan harus dimulai dengan usaha mengenal dan merumuskan keinginan dan kebutuhan dari konsumen. Kemudian perusahaan menyesuaikan kegiatannya agar dapat memuaskan kebutuhan konsumen dengan cara efektif dan efisien. Maksud dari efektif dan efisien disini adalah dalam pemenuhan kebutuhan konsumen harus tepat sasaran dan tepat waktu, yaitu apa yang diinginkan konsumen dan kapan konsumen menginginkannya.

Definisi konsep pemasaran menurut Philip Kotler (2002 : 17) adalah sebuah upaya pemasaran terkoordinasi yang berfokus pada pasar dan berorientasi pada pelanggan dengan tujuan memberikan kepuasan pada pelanggan sebagai kunci untuk mencapai tujuan organisasi.

\section{Produk dan Bauran Produk (Product Mix)}

a. Pengertian Produk

Definisi produk menurut Philip Kotler (2002: 13) adalah sebagai berikut "Produk merupakan segala sesuatu yang dapat ditawarkan ke suatu pasar untuk memenuhi segala keinginan atau kebutuhan". Produk-produk yang dipasarkan adalah meliputi barang fisik, jasa, pengalaman, peristiwa, orang, tempat, properti, organisasi, dan gagasan.

b. Bauran Produk (Product Mix) 
Definisi bauran (Product Mix) produk menurut Philip Kotler (2002: 145) adalah sebagai berikut "Bauran produk (product mix) adalah kumpulan dari semua produk dan unit produk yang ditawarkan penjual tertentu kepada pembeli." Bauran produk suatu perusahaan memiliki lebar, panjang, kedalaman, dan konsistensi tertentu. Konsep-konsep dimensi tersebut antara lain:

1. Lebar bauran produk

Lebar bauran produk mengacu pada berapa banyak macam lini produk yang ada pada suatu perusahaan.

2. Panjang bauran produk

Panjang bauran produk mengacu pada jumlah unit produk dalam bauran produk suatu perusahaan.

3. Kedalaman bauran produk

Kedalaman bauran produk mengacu pada berapa banyak varian yang ditawarkan tiap produk dalam lini produk suatu perusahaan.

4. Konsistensi bauran produk

Konsistensi bauran produk mengacu pada seberapa erat hubungan berbagai lini produk dalam hal penggunaan akhir, persyaratan produksi, saluran distribusi, atau hal lainnya.

Dari keempat dimensi bauran produk tersebut memungkinkan perusahaan untuk memperluas bisnisnya dengan empat cara, antara lain:

1. Perusahaan dapat menambah lini produk baru, sehingga memperlebar bauran produknya.

2. Perusahaan dapat memperpanjang tiap lini produk

3. Perusahaan dapat menambah lebih banyak varian produk dan memperdalam bauran produknya

4. Perusahaan dapat mengejar lagi konsistensi lini produk yang lebih kuat.

Dari uraian diatas dapat disimpulkan bahwa kelengkapan produk (barang) adalah semua jenis produk (barang) yang dapat ditawarkan kedalam pasar untuk diperhatikan, dimiliki, dipakai, atau dikonsumsi sehingga dapat memuaskan suatu keinginan atau suatu kebutuhan.

\section{Pelayanan}

Suatu kegiatan atau urutan kegiatan yang terjadi dalam interaksi langsung antara seseorang dengan orang lain atau mesin secara fisik, dan menyediakan kepuasan pelanggan. Dalam Kamus Besar Bahasa Indonesia dijelaskan pelayanan adalah usaha melayani kebutuhan orang lain. Sedangkan melayani adalah membantu menyiapkan (mengurus) apa yang diperlukan seseorang.

Menurut Sugiarto (2002:216) pelayanan adalah upaya maksimal yang diberikan oleh petugas pelayanan dari sebuah perusahaan untuk memenuhi harapan dan kebutuhan konsumen sehingga tercapai kepuasan. Pelayanan sering disebut sebagai jasa yang diberikan oleh perusahaan, artinya bahwa adanya suatu perbuatan yang dilaksanakan suatu pihak terhadap pihak lain.

Pelayanan Konsumen merupakan kegiatan yang berorientasi kepada konsumen yang terdiri dari elemen-elemen nyata berupa faktor yang bisa diraba, didengar dan dirasakan seperti ukuran, berat, warna dan sebagainya. Kemudian adanya elemen-elemen tidak nyata yaitu lebih sulit diukur dan seringkali subjektif karena tergantung pada sikap-sikap yang bisa dipengaruhi namun tidak diajarkan, sebagai contoh rasa nyaman, rileks, percaya dan lain sebagainya. Pelayanan yang berkualitas sangat mempengaruhi perilaku konsumen. Menurut Sunarto (2003:244) Ada tujuh dimensi dasar dari kualitas pelayanan, yaitu :

a. Kinerja, Yaitu tingkat absolute kinerja barang atau jasa pada atribut kunci yang identifikasi para konsumen.

b. Interaksi Pegawai, yaitu seperti keramahan, sikap hormat, dan empati ditunjukkan oleh masyarakat yang memberikan jasa atau barang.

c. Reliabilitasi, yaitu konsistensi kinerja barang, jasa dan toko.

d. Daya tahan, yaitu rentan kehidupan produk dan kekuatan umum.

e. Ketepatan waktu dan kenyamanan, yaitu seberapa cepat produk diserahkan atau diperbaiki, seberapa cepat cepat produk informasi atau jasa diberikan.

f. Estetika, yaitu lebih pada penampilan fisik barang atau toko dan daya tarik penyajian jasa.

g. Kesadaran akan merek, yaitu dampak positif atau negative tambahan atas kualitas yang tampak, yang mengenal merek atau nama toko atas evaluasi konsumen.

Dari uraian diatas dapat disimpulkan pelayanan merupakan faktor penting yang dapat menpengaruhi perilaku konsumen dalam berbelanja. 


\section{Perilaku Konsumen}

Menurut Basu Swastha dan T.Hani Handoko (2000: 10) Perilaku konsumen adalah kegiatankegiatan individu yang secara langsung terlibat mendapatkan dan menggunakan barang-barang dan jasajasa termasuk didalamnya proses pengambilan keputusan pada persiapan dan penentuan kegiatankegiatan tersebut.

Dari definisi di atas, ada dua elemen penting dari arti perilaku konsumen yaitu proses pengambilan keputusan dan kegiatan fisik. Adapun kedua elemen tersebut melibatkan individu dalam menilai, mendapatkan dan mempergunakan barang-barang dan jasa ekonomis.

Perilaku konsumen pada hakekatnya bukanlah hal yang mudah untuk dipelajari. Karena perilaku konsumen merupakan salah satu bagian dari perilaku manusia secara keseluruhan. Walaupun sulit untuk mempelajarinya, perilaku konsumen sangatlah penting bagi pemasar, karena dengan mengenal dan merumuskan keinginan dan kebutuhan konsumen maka akan diketahui produk yang bagaimana yang dapat memuaskan konsumen tersebut. Sebagai bagian dari perilaku manusia secara keseluruhan, konsumen akan berperilaku bila ada kesenjangan antara keadaan yang sesungguhnya dengan keadaan yang diharapkan dari kebutuhan dan keinginan yang ingin dialami.

\section{Faktor-Faktor Yang Mempengaruhi Perilaku Konsumen}

Secara umum faktor yang mempengaruhi perilaku konsumen dapat digolongkan menjadi dua, yaitu:

1. Faktor Lingkungan Eksternal

Faktor lingkungan eksternal yang paling mempengaruhi perilaku kosumen adalah lapisan masyarakat dimana ia dilahirkan dan dibesarkan. Ini berarti bahwa konsumen yang berasal dari lapisan masyarakat atau lingkungan yang berbeda akan mempunyai penilaian, kebutuhan, pendapatan, sikap dan selera yang berbeda-beda. Faktor-faktor eksternal yang mempengaruhi konsumen dapat dibedakan sebagai berikut:

a. Kebudayaan

Manusia dengan kemampuan akal budaya telah mengembangkan berbagai macam sistem perilaku demi keperluan hidupnya. Namun berbagai macam sistem perilaku tadi harus dibiasakan olehnya dengan belajar sejak lahir. Aspek belajar menyediakan cara hidup manusia dengan sistem perilaku sebagai "Kebudayaan". Kebudayaan merupakan simbol dan fakta yang komplek yang diciptakan oleh manusia diturunkan dari generasi ke generasi sebagai penentu dan pengatur perilaku manusia dalam masyarakat yang ada.

b. Kebudayaan Khusus

Dalam suatu masyarakat yang mempunyai jumlah anggota yang besar dan menempati daerah yang luas, terdapat perbedaan-perbedaan kebudayaan dalam berbagai bidang di daerah tersebut. Kebudayaan yang khusus ada pada suatu golongan masyarakat yang berbeda dari kebudayaan masyarakat lain. Inilah yang disebut sebagai kebudayaan khusus. Dengan demikian maka perilaku konsumen yang mempunyai kebudayaan ini akan berbeda dengan perilaku konsumen secara keseluruhan walaupun dalam satu lingkup kebudayaan.

c. Kelas Sosial

Kelas sosial adalah kelompok yang relatif permanen dan homogen dalam sebuah masyarakat. Anggota-anggota kelasnya mempunyai nilai, guna hidup, minat dan perilaku yang serupa. Umumnya tingkat pendidikan dan pekerjaan merupakan indikator kelas sosial yang paling akurat. Kelas sosial seseorang menunjukkan pola hidup orang yang bersangkutan.

Orang yang berasal dari sub-budaya yang sama, kelas sosial yang sama dan bahkan pekerjaan yang sama dapat mempunyai gaya hidup yang berbeda. Banyak orang yang dari kelas sosial yang lebih rendah berusaha meniru anggota kelas yang lebih tinggi dengan membeli barang dan jasa yang serupa dan perilaku pembelian mereka dipengaruhi persepsi mereka akan kelas sosial. Jadi sampai sejauh mana pemasaran mampu mempromosikan produknya sehingga dirasakan bisa membantu kegiatan konsumen untuk mencapai kelas sosial yang lebih tinggi.

Pada umumnya, masyarakat kita dapat dikelompokkan ke dalam tiga golongan masyarakat sebagai berikut:

- Golongan atas, yang termasuk di dalam golongan ini antara lain: pejabat tinggi, pengusaha kaya.

- Golongan menengah, yang termasuk di dalam golongan ini antara lain: pengusaha menengah, karyawan instansi pemerintah.

- Golongan Rendah, yang termasuk di dalamnya antara lain: pengusaha kecil, buruh, tukang dan pedagang kecil. 
Pembagian masyarakat menjadi tiga golongan ini sangat relatif tergantung kepada tingkat pendapatan, jenis usaha, macam perusahaan dan lokasi tempat tinggal.

d. Keluarga

Keluarga digambarkan untuk berbagai macam bentuk rumah tangga. Yang dimaksud dalam bentuk rumah tangga yaitu "Keluarga Inti", meliputi Ayah, Ibu, dan anak-anak yang hidup bersama, serta "Keluarga Besar", yaitu keluarga inti ditambah dengan orang-orang yang mempunyai ikatan saudara dengan keluarga tersebut, seperti kakak, nenek, paman, bibi, dan menantu. Dalam pasar konsumen, keluargalah yang paling banyak membeli dan mengkonsumsi produk. Pembelian tiap anggota keluarga berbeda-beda dan bermacam-macam tergantung dari kebutuhan dan selera dari masing-masing anggota keluarga. Jadi pihak manajer perusahaan dalam mengidentifikasikan perilaku harus dapat mengetahui siapa yang menjadi inisiatif, penentu, pembeli atau siapa yang mempengaruhi suatu keputusan dalam membeli.

e. Kelompok Referensi

Perilaku seseorang sangat dipengaruhi oleh berbagai kelompok. Sebuah kelompok referensi bagi seseorang adalah kelompok-kelompok yang memberikan pengaruh langsung atau tidak langsung terhadap sikap dan perilaku seseorang. Kelompok yang memberikan pengaruh langsung kepada seseorang disebut kelompok keanggotaan, yakni dimana seseorang menjadi anggotanya dan saling berinteraksi. Orang juga mempengaruhi kelompok-kelompok dimana ia bukan merupakan anggotanya. Kelompok yang ingin menjadi anggotanya disebut kelompok aspirasi.

f. Demografi

Demografi digambarkan untuk menggambarkan suatu populasi kedalam istilah-istilah seperti ukuran, struktur dan distribusi. Ukuran adalah untuk menggambarkan angka atau nomor dalam individu dalam suatu populasi. Struktur sendiri menggambarkan populasi kedalam istilahistilah umur, pendapatan, pendidikan dan pekerjaan. Sedangkan distribusi dari suatu populasi menggambarkan lokasi dan individu-individu tersebut kedalam suatu istilah geografi suatu daerah dan desa, daerah perkotaan atau lokasi pinggiran kota. Masing-masing dari faktor tersebut mempengaruhi perilaku konsumen dan menyumbang secara keseluruhan dari suatu permintaan untuk bermacam-macam barang atau jasa.

2. Faktor Lingkungan Internal

Faktor-faktor psikologis yang berasal dari proses intern individu sangat berpengaruh terhadap perilaku pembelian konsumen. Dalam memberikan pengetahuan yang sangat penting tentang alasanalasan yang menyangkut perilaku konsumen, maka teori-teori psikologis yang menjadi dasar perilaku konsumen adalah sebagai berikut:

a. Motivasi

Yang dimaksud dengan motivasi adalah keadaan dalam diri pribadi seseorang yang mendorong keinginan individu untuk melakukan kegiatan-kegiatan tertentu guna mencapai tujuan. Motif yang ada pada diri seseorang akan mengakibatkan suatu perilaku yang diarahkan mencapai sasaran kepuasan. Jadi secara definitif dapat dikatakan bahwa motivasi adalah suatu dorongan kebutuhan dan keinginan individu yang diarahkan pada tujuan untuk memperoleh kepuasan.

b. Pengamatan

Adalah suatu proses dengan nama manusia atau konsumen menyadari dan menginterprestasikan aspek lingkungan intern dan ekstern., maka rangsangan tersebut mempunyai pengaruh yang besar terhadap pengamatan seseorang dalam tingkah laku, pengalaman ini diperoleh dari suatu kejadian di masa lampau yang dapat dipelajari. Hasil dari pengalaman individu ini akan membentuk suatu pandangan tertentu bagi individu tersebut dan pengalaman antara individu yang satu dengan yang lain akan berbeda sehingga dalam perilaku akan berbeda pula. Dalam penelitian yang dilakukan konsumen, merupakan proses belajar dimana hal ini merupakan bagian dari hidup konsumen. Proses belajar dalam pembelian terjadi apabila konsumen ingin menanggapi dan memperoleh kepuasan atau sebaliknya. Tanggapan konsumen sangat dipengaruhi oleh pengalaman lampau dan apabila konsumen mendapatkan suatu kepuasan, maka tanggapan positif terhadap suatu produk dan adanya kecenderungan untuk mengadakan suatu pembelian kembali atas produk yang sama apabila dibutuhkan selama produk-produk tersebut memberikan kepuasan dan kombinasi petunjuk tidak berubah. Demikian sebaliknya, apabila kepuasan dari produk yang dibelinya tidak diperolehnya, maka kebiasaan akan membeli produk tersebut akan berkurang atau mempunyai tanggapan yang negatif terhadap produk tersebut.

c. Sikap

Sikap (attitude) seseorang adalah prodeposisi (keadaan mudah terpengaruh) dalam memberikan tanggapan terhadap rangsangan lingkungan, hal ini juga merupakan hasil dari proses belajar yang 
selalu berhubungan dengan obyek tertentu yang memberikan suatu penilaian berupa persetujuan yang berarti menerima atau menolak obyek tersebut, sehingga apabila kita kaitkan obyek tersebut sebagai suatu produk, maka akan terjadi suatu proses penerimaan atau penolakan produk tersebut. Dalam penilaian untuk menentukan diterima atau ditolak suatu produk, maka akan dipengaruhi oleh keadaan jiwa (dipengaruhi oleh tradisi, kebiasaan dari kebudayaan, sebagainya) dan keadaan berfikir yang dipengaruhi oleh tingkat pendidikan seseorang.

\section{Proses Keputusan Membeli.}

Perilaku konsumen ini akan menentukan proses pengambilan keputusan dalam pembelian mereka. Proses keputusan membeli ini terdiri dari lima tahap, yaitu: pengenalan masalah (problem recognition), pencarian informasi (information research), evaluasi alternatif (evolution of alternatives), keputusan pembelian (purchase decision) dan perilaku purna pembelian (post purchase behavior). Adapun kelima tahap proses membeli tersebut terlihat pada gambar berikut.

\begin{tabular}{|c|c|c|c|c|}
\hline $\begin{array}{c}\text { Pengenalan } \\
\text { Masalah }\end{array}$ & $\begin{array}{l}\text { Pecarian } \\
\text { Informasi }\end{array}$ & $\begin{array}{c}\text { Evaluasi } \\
\text { Alternatif }\end{array}$ & $\begin{array}{l}\text { Keputusan } \\
\text { pembelian }\end{array}$ & $\begin{array}{c}\text { Perilaku } \\
\text { Setelah } \\
\text { Pembelian }\end{array}$ \\
\hline
\end{tabular}

Gambar 1. Proses Keputusan Membeli

Kelima tahap tersebut di atas dapat diuraikan sebagai berikut:

a. Pengenalan Masalah

Proses pembelian dimulai dengan pembeli mengenali suatu masalah dalam hal ini kebutuhannya dan menganalisanya. Hal tersebut dilakukan untuk mengetahui adanya keinginan dan kebutuhan yang belum terpenuhi atau terpuaskan. Jika kebutuhan tersebut diketahui, maka kosumen akan segera memahami adanya suatu kebutuhan yang belum perlu dipenuhi atau masih bisa ditunda pemenuhannya serta kebutuhan-kebutuhan yang sama-sama harus dipenuhi.

b. Pencarian Informasi

Inti yang terpenting dari pemasar adalah sumber informasi utama yang digunakan oleh konsumen dan tiap pengaruh terhadap keputusan pembelian. Sumber informasi konsumen tergolong dalam empat kelompok, yaitu:

1. sumber personal (keluarga, teman, tetangga dan kenalan)

2. sumber komersial (periklanan, tenaga penjual, pedagang, kemasan dan pameran)

3. sumber publik (media masa, organisasi, penilaian konsumen)

4. sumber eksperimental (penanganan, pengujian, penggunaan produk)

Mengenai sumber informasi yang digunakan oleh konsumen, pemasar harus dengan cermat mengidentifikasikan dalam arti penting sumber sebagai sumber informasi.

c. Evaluasi alternatif

Tahap ini melalui 2 proses, yaitu

- Menetapkan tujuan pembelian dan menilainya

- Mengadakan seleksi terhadap alternatif pembelian berdasarkan tujuan pembelian.

Setelah tujuan pembelian ditetapkan, konsumen perlu mengidentifikasikan alternatif-alternatif pembeliannya yang tidak dapat terpisahkan dari pengaruh sumber-sumber yang memiliki (waktu, uang dan informasi) maupun resiko keliru dalam pemilihan. Alternatif pembelian yang telah diidentifikasikan, dinilai dan diseleksi menjadi alternatif pembelian yang dapat memenuhi dan memuaskan kebutuhan serta keinginannya. Adapun kriteria evaluasi menyangkut ciri-ciri produk pemberian bobot yang penting pada ciri-ciri relevan, kepercayaan terhadap merek, fungsi utilitas dan sikap konsumen ke arah alternatif merk melalui informasi tertentu.

d. Keputusan membeli

Keputusan membeli disini merupakan proses dalam pembelian yang nyata. Jadi setelah melakukan tahap-tahap di atas, maka konsumen harus mengambil keputusan apakah membeli atau tidak. Bila konsumen memutuskan untuk membeli, konsumen akan menjumpai serangkaian keputusan yang harus diambil menyangkut jenis produk, merk, penjual, kualitas, waktu pembelian dan cara pembayarannya. Keputusan membeli ini sangat dipengaruhi oleh sikap orang lain dan faktorfaktor situasional yang tidak diinginkan seperti pendapatan keluarga yang diharapkan dan manfaat yang diharapkan dari produk tersebut. Sehingga menghasilkan keputusan membeli.

e. Perilaku setelah pembelian

Setelah membeli suatu produk, konsumen akan mengalami suatu tingkat kepuasan atau tidak puas. Jika konsumen merasa puas mereka akan memperhatikan suatu kemungkinan besar untuk 
membeli produk tersebut pada kesempatan lain. Disamping itu ada konsumen merasa tidak puas setelah pembelian, hal ini terjadi karena harga produk tersebut terlalu mahal, atau kemungkinan karena tidak sesuai dengan keinginan atau persepsi sebelumnya. Untuk mengurangi jumlah konsumen yang tidak puas setelah pembelian tersebut, perusahaan harus melihat dan bertindak dengan menekankan pada segi-segi tertentu yang diunggulkan atau servis tertentu dari pelayanannya.

\section{KERANGKA ANALISIS}

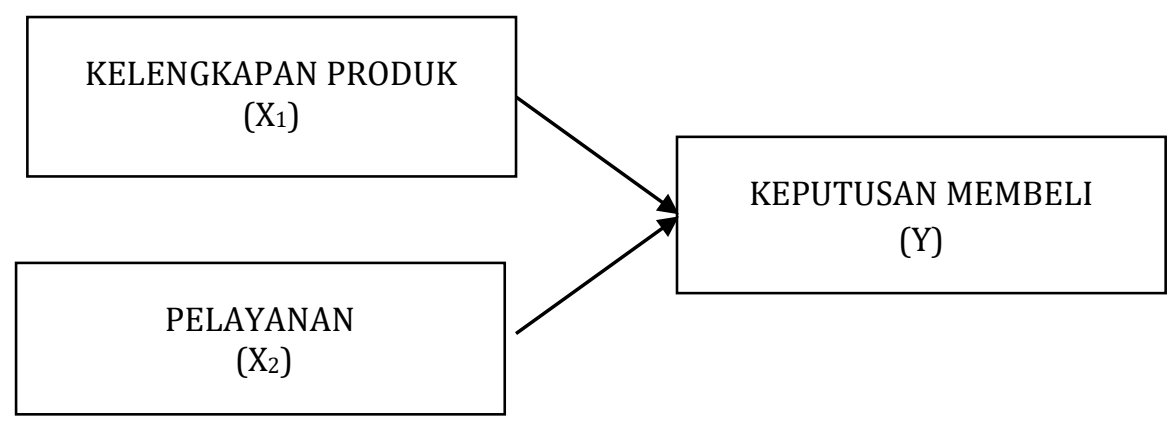

Gambar 2. Kerangka Analisis

\section{Hipotesis}

Hipotesis adalah pernyataan singkat yang merupakan jawaban sementara terhadap masalah yang diteliti serta masih perlu diuji kebenarannya. Hipotesis perlu diuji, maka dari itu diperlukan sejumlah data baik yang mendukung maupun yang bertentangan dengan hipotesis. Data tersebut akan diolah dengan membuktikan perhitungan statistik guna memperoleh kesimpulan-kesimpulan untuk membuktikan kebenaran hipotesis. Dalam penelitian ini hipotesis yang diajukan penulis sebagai berikut:

"Bahwa Kelengkapan Produk Dan Pelayanan Mempunyai Pengaruh Positif dan Terukur Terhadap Keputusan Membeli Dalam Berbelanja Pada Zan Mart Di Kabupaten Bengkulu Selatan secara bersama-sama maupun secara parsial".

\section{METODOLOGI}

Teknik pengumpulan data dalam penelitian ini menggunakan dokumentasi. Data sekunder berupa potensi dan realisasi retribusi pasar umum di kota Bengkulu diperoleh dari Dinas Perindustrian dan Perdagangan Kota Bengkulu. Dalam menganalisis potensi retribusi pasar umum di kota Bengkulu, digunakan rumus potensi retribusi pasar menurut Mahmudi (2010) sebagai berikut: Metode yang digunakan untuk menganalisa data masukan dalam penelitian menggunakan berbagai cara yang dijelaskan seperti berikut:

a. Analisa Kualitatif

Analisa kualitatif yaitu membandingkan antara teori yang ada dengan factor-faktor yang mempengaruhi perilaku konsumen dalam berbelanja pada Zan Mart yang terdiri dari Kelengkapan Produk dan Pelayanan.

b. Analisa Kuantitatif

Yaitu alat analisa yang menggunakan rumus statistic regresi linier berganda menurut (Djarwanto Ps, 2004 : 310) dengan persamaan :

1. $Y=a+b_{1} X_{1}+b_{2} X_{2}$

Dimana :

$$
\begin{array}{ll}
\mathrm{Y} & =\text { Perilaku Konsumen } \\
\mathrm{a} & =\text { Konstanta } \\
\mathrm{b}_{1} & =\text { Koefisien regresi } \mathrm{X}_{1} \\
\mathrm{~b}_{2} & =\text { Koefisien regresi } \mathrm{X}_{2} \\
\mathrm{X}_{1} & =\text { Kelengkapan Produk } \\
\mathrm{X}_{2} & =\text { Pelayanan }
\end{array}
$$

Nilai koefisien a dan $\mathrm{b}_{1} \mathrm{X}_{1}, \mathrm{~b}_{2} \mathrm{X}_{2}$ diperoleh dengan rumus sebagai berikut : 


$$
\begin{aligned}
& a=Y-b_{1} X_{1}-b_{2} X_{2} \\
& b_{1}=\frac{\left(\sum X_{2}^{2}\right)\left(X_{1 . Y} Y-\left(X_{1} X_{2}\right)\left(X_{2} . Y\right)\right.}{\left(\sum X_{1}^{2}\right)\left(\sum X_{2}^{2}\right)-\left(X_{1} X_{2}\right)^{2}} \\
& b_{2}=\frac{\left(\sum X_{1}^{2}\right)\left(X_{2 .} Y\right)-\left(X_{1} X_{2}\right)\left(X_{1 . Y} Y\right)}{\left(\sum X_{1}^{2}\right)\left(\sum X_{2}^{2}\right)-\left(X_{1} X_{2}\right)^{2}}
\end{aligned}
$$

Untuk mengukur keeratan hubungan antara masing-masing variabel pengaruh dengan variable terpengaruh koefesien parsial dengan rumus (Djarwanto Ps, 2004 : 354) :

2. Korelasi Berganda

$$
\begin{aligned}
& R^{2} \quad=\frac{b_{1} \sum X_{1} Y+b_{2} \sum X_{2} Y}{\Sigma Y} \\
& \text { Yang mana : } \\
& \mathrm{R}^{2} \quad=\text { Koefesien korelasi berganda }
\end{aligned}
$$

3. Korelasi parsial

$$
\begin{aligned}
& r_{y 1}=\frac{n \sum X_{1} Y-\Sigma X_{1} \sum Y}{\left.\sqrt{\left\{\sum X_{1}^{2}-\left(\sum X_{1}\right)^{2} n \sum Y^{2}-(\Sigma Y)^{2}\right.}\right\}} \\
& n \sum X_{2} Y-\sum X_{2} \sum Y
\end{aligned}
$$

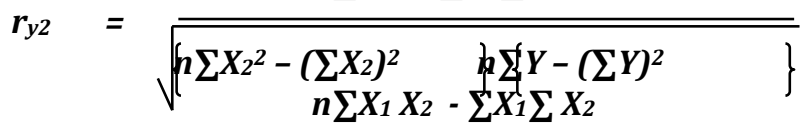

$$
\begin{aligned}
& r_{y 12}=\sqrt{\left\{n \sum X_{1}^{2}-\left(\sum X_{1}\right)^{2}(\} n\left\{X_{2}^{2}-(\Sigma X)^{2}\right\}\right.} \\
& \text { Dimana : } \\
& r_{\boldsymbol{y} 1}=\text { Koefisien korelasi antara } \mathrm{Y} \text { dan } \mathrm{X}_{1} \text {, Apabila } \mathrm{X}_{2} \text { tetap } \\
& r_{y 2}=\text { Koefisien korelasi antara } \mathrm{Y} \text { dan } \mathrm{X}_{2} \text {, Apabila } \mathrm{X}_{1} \text { tetap } \\
& r_{y 12}=\text { Koefesien korelasi antara } \mathrm{X}_{1} \text { dan } \mathrm{X}_{2}
\end{aligned}
$$

\section{Uji F}

Digunakan untuk menguji secara keseluruhan keeratan hubungan antara variabel, dengan rumus sebagai berikut :

$$
\left.F=\frac{R^{2} /(k-1)}{\left(1-R^{2}\right) /(n-k)} \quad \text { J. Suprapto, } 2000: 190\right)
$$

Dimana :

$\mathrm{R}^{2}=$ Koefesien determinasi

$\mathrm{n}=$ Jumlah data

$\mathrm{k}=$ Jumlah variable

Langka pengujian :

$H_{0}: H_{i}=0$ Tidak ada hubungan antara variable $X_{1}, X_{2}$ dengan $Y$

$\mathrm{H}_{\mathrm{a}}: \mathrm{b}_{\mathrm{i}} \neq 0$ ada hubungan antara variable $\mathrm{X}_{1}, \mathrm{X}_{2}$ dengan $\mathrm{Y}$

Digunakan level of signifikan $95 \%$ atau $\alpha \quad 0,05$

- Jika $F_{\text {hitung }} \leq \mathrm{F}$ table, maka $\mathrm{H}_{0}$ Diterima

- Jika $F_{\text {hitung }} \geq \mathrm{F}_{\text {table, }}$ maka $\mathrm{H}_{\mathrm{a}}$ Diterima

5. Ujit

Untuk menghitung nilai t digunakan rumus sebagai berikut :

$$
t_{\text {hitung }} X_{1}=r \sqrt{\frac{n-2}{1-r^{2}}}
$$

(DJarwanto Ps, 2004 : 324) 


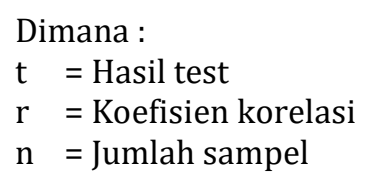

Dengan ketentuan :

a. H0 : $\rho=0$ (tidak ada hubungan antara variable $\mathrm{X}$ dan $\mathrm{Y}$ )

$\mathrm{Hi}: \rho=0$ (ada hubungan antara variable $\mathrm{X}$ dan $\mathrm{Y}$ )

- $\quad$ Level of signifikan $(\alpha)$ 5\%

- Keriteria pengujian

Ho Diterima apabila $\quad t(\alpha / 2: n-1) \leq t \leq(\alpha / 2: n-1)$

Ho Ditolak apabila $\quad \mathrm{t}(\geq \mathrm{t}(\alpha / 2: \mathrm{n}-1))$ atau

$\mathrm{t}(<-\mathrm{t}(\alpha / 2: \mathrm{n}-1))$

\section{HASIL PENELITIAN DAN PEMBAHASAN}

Hasil pengujian koefisien korelasivariabel $\left(\mathrm{X}_{1}\right)$ kelengkapan produk, variabel $\left(\mathrm{X}_{2}\right)$ pelayanan danvaribel $(\mathrm{Y})$ keputusan membeli adalah besarnya nilai thitung darimasing-masing variabel dapat dilihat bahwa nilai kritis atau tabeluntuk uji satu pihak pada taraf signifikansi $5 \%$ adalah $\alpha / 2: \mathrm{n}-1=1,980$, dari hasil tersebut dapat diambil kesimpulan bahwa :

1. Nilai thitung koefisien korelasi dari variabel $\left(\mathrm{X}_{1}\right)$ kelengkapan produk dangan (Y) keputusan membeli lebih besar dari tabel atau thitung $>t_{\text {tabel }}=13,9481>1,980$.

2. Nilai thitung koefisien korelasi dari variabel $\left(\mathrm{X}_{2}\right)$ pelayanan dengan $(\mathrm{Y})$ keputusan membelilebih besar dari $t_{\text {tabel }}$ atau $t_{\text {hitung }}>t_{\text {tabel }}=7,8455>1,980$.

3. Nilai thitung koefisien korelasi dari variabel $\left(\mathrm{X}_{1}\right)$ kelengkapan produk dan $\left(\mathrm{X}_{2}\right)$ pelayanan lebih besar dari $t_{\text {tabel }}$ atau thitung $>t_{\text {tabel }}=4,660>1,980$.

4. Nilai thitung koefisien korelasi dari variabel $\left(\mathrm{X}_{1}\right)$ kelengkapan produk dan $\left(\mathrm{X}_{2}\right)$ pelayanan dengan $(\mathrm{Y})$ keputusan membeli lebih besar dari ttabel atau thitung $>t_{\text {tabel }}=117,85>1,980$.

Sehingga korelasi antara variabel ( $\mathrm{X}_{1}$ ) kelengkapan produk dengan variabel ( $\mathrm{Y}$ ) keputusan membeli, korelasi antara variabel $\left(\mathrm{X}_{2}\right)$ pelayanan dengan variabel $(\mathrm{Y})$ keputusan membeli, korelasi antara variabel $\left(\mathrm{X}_{1}\right)$ kelengkapan produk dengan variabel $\left(\mathrm{X}_{2}\right)$ pelayanan serta korelasi antara variabel $\left(\mathrm{X}_{1}\right)$ kelengkapan produk dan variabel $\left(\mathrm{X}_{2}\right)$ pelayanan dengan variabel $(\mathrm{Y})$ keputusan membeli mempunyai hubungan yang positif dan terukur.

\section{KESIMPULAN}

1) Ada pengaruh positif dan terukur antara kelengkapan produk dan pelayanan terhadap keputusan membeli pada Zan Mart di Kabupaten Bengkulu Selatan.

2) Berdasarkan hasil perhitungan diperoleh koefesien regresi linear berganda sebagai berikut:

- Konstanta (a) = 0,0223.

- Koefisien regresi $\left(b_{1}\right)=0,631$.

- Koefisien regresi $\left(b_{2}\right)=0,282$.

Dan diperoleh persamaan regresi $\mathbf{Y}=\mathbf{0 , 0 2 2 3}+\mathbf{0 , 6 3 1 X _ { 1 }}+\mathbf{0 , 2 8 2} \mathbf{X}_{2}$.

Persamaan bertanda positif (+), artinya setiap kenaikan variabel independent akan diikuti oleh kenaikan variabel dependent.

3) Berdasarkan hasil perhitungan diketahui $F_{\text {hitung }}>F_{\text {tabel }}$ yaitu 6887,47 $>3,09$. Dengan demikian Ho ditolak dan Ha diterima. Artinya secara simultan kelengkapan produk dan pelayanan berpengaruh positif dan terukur terhadap keputusan membeli dalam berbelanja pada Zan Mart di Kabupaten Bengkulu Selatan secara bersama-sama maupun secara parsial diterima.

4) Hasil pengujian koefisien korelasi baik secara parsial maupun bersama-sama antara variabel $\left(X_{1}\right)$ kelengkapan produk, variabel $\left(\mathrm{X}_{2}\right)$ pelayanan dan varibel $(\mathrm{Y})$ keputusan membeli adalah :

- Nilai thitung koefisien korelasi dari variabel ( $\mathrm{X}_{1}$ ) kelengkapan produk dangan (Y) keputusan membeli lebih besar dari $t_{\text {tabel }}$ atau $t_{\text {hitung }}>t_{\text {tabel }}=13,9481>1,980$ sehingga Ho ditolak. Artinya secara parsial terdapat hubungan yang positif dan terukur antara kelengkapan produk dan keputusan membeli sebesar 0.665 (66,5\%).

- $\quad$ Nilai thitung koefisien korelasi dari variabel $\left(\mathrm{X}_{2}\right)$ pelayanan dengan (Y) keputusan membeli lebih besar dari tabel atau $t_{\text {hitung }}>t_{\text {tabel }}=7,8455>t_{\text {tabel }} 1,980$ sehingga Ho ditolak. Artinya secara parsial terdapat hubungan yang positif dan terukur antara pelayanan dan keputusan membeli sebesar $0.386(38,6 \%)$. 
- $\quad$ Nilai thitung koefisien korelasi dari variabel $\left(\mathrm{X}_{1}\right)$ kelengkapan produk dan $\left(\mathrm{X}_{2}\right)$ pelayanan lebih besar dari $t_{\text {tabel }}$ atau $t_{\text {hitung }}>t_{\text {tabel }}=4,660>1,980$ sehingga Ho ditolak. Hal ini berarti terdapat hubungan positif dan terukur antara pelayanan dan kelengkapan produk sebesar 0.1812 $(18,12 \%)$.

- Nilai thitung koefisien korelasi dari variabel $\left(\mathrm{X}_{1}\right)$ kelengkapan produk dan $\left(\mathrm{X}_{2}\right)$ pelayanan dengan (Y) keputusan membeli lebih besar dari ttabel atau thitung $>$ tabel $=117,85>1,980$ Ho ditolak. Artinya secara simultan yang terdapat hubungan positif dan terukur antara kelengkapan produk, pelayanan dan keputusan membeli sebesar $0.993(99,3 \%)$.

\section{SARAN}

1. Sikap konsumen dipengaruhi oleh evaluasi dan kepercayan pelanggan, oleh karena itu pihak Zan Mart dapat mengupayakan agar senantiasa lebih mempertahankan atau bahkan meningkatkan kelengkapan produk dan meningkat pelayanan agar kepuasan pelanggan atau konsumen dalam berbelanja dapat bertambah, dengan sendirinya maka tingkat kepercayaan konsumen akan semakin tinggi dan evaluasi akan semakin bagus.

2. Zan Mart adalah sebuah mini market yang ditujukan untuk memenuhi kebutuhan masyarakat dan seharusnyalah pihak Zan Mart meningkatkan kualitas pelayan terhadap konsumen, karena pelayanan yang kurang berkualitasi akan membuat nilai kepuasan pelanggan akan menurun serta kelengkapan produk dan pelayanan yang baik dapat menjadi sarana promosi bagi Zan Mart.

3. Untuk atribut-atribut yang diuji sendiri, sudah bagus, hanya perlu ditingkatkan untuk menambah kenyamanan dan kepuasan konsumen dalam berbelanja. Penataan ulang terhadap produk-produk dapat dilakukan untuk menyegarkan suasana agar lebih menyenangkan bagi konsumen dalam berbelanja, tetapi diusahakan tidak menyusahkan konsumen dalam mencari barang.

4. Pihak Zan Mart dapat mencari strategi pemasaran (marketing mix) yang baru untuk dapat meningkatkan kepuasan pelanggan dan meningkatkan nilai penjualan.

\section{DAFTAR PUSTAKA}

Basu Swasta, dan Handoko, T Hani., 2000, Manajemen Pemasaran, Analisis, PerilakuKonsumen, Liberty, Yogyakarta.

Basu Swasta, 2003, Konsep Pemasaran, Liberty, Yogyakarta.

J. Suprapto, Pengukuran Tingkat Kepuasan Pelanggan Untuk Meningkatkan Pangsa Pasar, Rineka Cipta, Jakarta.

Philip Kotler, 2002, Manajemen Pemasaran, Jakarta: Erlangga.

Sugiyono dan Eri Wibowo, 2002, Statistika Penelitian, Bandung.

William J, Stanton, 2003, Prinsip Pemasaran, Edisi Ketujuh, Jilid Kedua, Erlangga, Jakarta.

Djarwanto Ps, 2004, Metodologi Penelitian, Bandung. 